\title{
D4-GDI is cleaved by caspase-3 during daunorubicin-induced apoptosis in HL-60 cells
}

\author{
Kang-Beom Kwon ${ }^{1}$, Eun-Kyung Park ${ }^{2}$, \\ Do-Gon Ryu ${ }^{1}$ and Byung-Hyun Park ${ }^{2,3}$ \\ ${ }^{1}$ Department of Physiology, School of Oriental Medicine,
Won-Kwang University, Iksan 570-749, Chonbuk, Korea
${ }^{2}$ Department of Biochemistry and Institute for Medical Sciences,
Chonbuk National University, Medical School, Chonju 561-756,
Chonbuk, Korea
${ }^{3}$ Corresponding author: Tel, +82-63-270-3139;
Fax, +82-63-274-9833; E-mail, bhpark@moak.chonbuk.ac.kr
}

Accepted 2 January 2002

Abbreviations: Ac-DEVD-CHO, N-acetyl-Asp-Glu-Val-Asp-CHO (aldehyde); Ac-DEVD-AFC, N-acetyl-Asp-Glu-Val-Asp-AFC (7-amino4-trifluoromethyl-coumarine); Ac-YVAD-CHO, N-acetyl-Tyr-Val-AlaAsp-CHO (aldehyde); GDI, GDP-dissociation inhibitor; ICAD, an inhibitory protein for the caspase-activated deoxyribonuclease (CAD); ICE, IL-13-converting enzyme; LPS, lipopolysaccharide; MAPK, mitogen activated protein kinase; MTT, 3-(4,5-dimethylthiazol-2-yl)-2,5-diphenyltetrazolium bromide; PARP, poly(ADP-ribose) polymerase.

\begin{abstract}
Daunorubicin, an anti-cancer drug, is known to induce apoptosis in HL-60 cells in a dose-dependent manner through the activation of caspase-3 (CPP32). Caspase-3 selective inhibitor, Ac-DEVD-CHO, prevented both the activation of caspase-3 and cleavage of poly(ADP-ribose) polymerase (PARP). D4-GDI is a GDP dissociation inhibitor for the Ras-related Rho family GTPase in hematopoietic cells. Here we report that D4-GDI is a substrate for the caspase-3. D4-GDI was cleaved to a $23 \mathrm{kDa}$ fragment by daunorubicin treatment in HL-60 cells with kinetics that parallel the onset of apoptosis. D4-GDI cleavage as well as DNA fragmentation was inhibited by treatment with Ac-DEVD-CHO but not with Ac-YVAD$\mathrm{CHO}$, a caspase-1 inhibitor. These data suggest that D4-GDI of Rho family GTPase may be regulated during apoptosis through the caspase-3 mediated cleavage of the GDI protein.
\end{abstract}

Keywords: daunorubicin, caspase-3, D4-GDI, poly(ADPribose) polymerase, apoptosis

\section{Introduction}

Daunorubicin is widely used in the treatment of acute myeloid leukemia (AML). Despite the extensive and generalized use for more than 30 years, its cytotoxic mechanism remains still obscure. Several hypotheses have been suggested including DNA intercalation, inhibition of topoisomerase II, free radical generation with consequent DNA damage or lipid peroxidation, DNA alkylation and cross-linking, and direct membrane effects (Gewirtz, 1999). Recently, it has been shown that stimulation of ceramide synthesis (Bose et al., 1995; Jaffrezou et al., 1996) or caspase activation (Gamen et al., 1997; Turnbull et al., 1999) mediate daunorubicin-induced apoptosis. Activation of caspase, a family of cysteine protease, has been demonstrated in different pathways of apoptosis (Polverino and Patterson, 1997). Caspase is synthesized as catalytically inactive proenzymes comprising a large and a small subunit with a variable length amino-terminal prodomain. On activation, the prodomain is lost by catalytic cleavage of carboxy-terminal at an aspartate residue, with heterodimerization of the large and small subunits to form the active enzyme (Nicholson and Thornberry, 1997). Numerous substrates for caspase were identified. Those include poly(ADP-ribose) polymerase (PARP) (Lazebnik et al., 1994), lamin (Oberhammer et al., 1994), DNA fragmentation factor (DFF/ICAD) (Liu et al., 1997), and gelsolin (Kothakota et al., 1997). Although many proteins are cleaved during apoptosis, a role of this cleavage has been identified only in a few of them. ICAD is cleaved by caspase- 3 , which leads to the release of DNase and causes subsequent DNA digestion during apoptotic process (Enari et al., 1998). Cleavage of gelsolin and lamin cause the characteristic morphological changes for apoptosis (Rao et al., 1996; Kothakota et al., 1997).

In resting cells, members of the Rho family exist as an inactive cytosolic complex with a class of regulatory protein known as a GDP dissociation inhibitor (GDI) (Bokoch and Der, 1993; Geyer and Wittinghofer, 1997) and three forms of GDI were identified: RhoGDI-1, RhoGDI-2 (also called D4/Ly-GDI), and RhoGDI-3. D4-GDI is specifically expressed in human and murine hematopoietic tissues, predominately in B- and T-lymphocyte cell lines (Lelias et al., 1993; Scherle et al., 1993). This protein binds to a majority of the Rho family GTPase and keeps the Rho protein in its GDP-bound inactive state incapable of interacting with effector targets or other regulatory 
proteins (Bokoch and Der, 1993; Olofsson, 1999). The Rho family of small GTPase regulates many cellular processes including actin polymerization that leads to the formation of stress fibers and focal adhesions (Ridley and Hall, 1992; Sasaki and Takai, 1998), generation of superoxide in activated neutrophils and macrophages (Abo et al., 1991; Guillemot et al., 1996), and the stress response through activation of c-Jun $\mathrm{N}$-terminal kinase and p38 MAPK2 (Coso et al., 1995; Minden et al., 1995; Zhang et al., 1995; Narumiya, 1996).

It has been reported that D4-GDI is cleaved by caspase-1 in LPS- or nigercin-treated inflammatory cells (Danley et al., 1996). D4-GDI is also reported to be cleaved by caspase-3 during apoptosis in Jurkat T-cells treated with anti-Fas antibody, staurosporine ( $\mathrm{Na}$ et al., 1996), and overexpressed Bax (Xiang et al., 1996), in BL60 Burkitt lymphoma cells treated with anti-lgM (Rickers et al., 1998) and taxol (Essmann et al., 2000), and in polymorphonuclear neutrophils treated with TNF- $\alpha$ (Kettritz et al., 2000). In this report, we add the observations that D4-GDI is a substrate of caspase-3 in HL-60 cells after induction of apoptosis by daunorubicin. By using cell permeable peptide inhibitors, we were able to demonstrate that caspase-3 is involved in D4-GDI cleavage and apoptosis after treatment with daunorubicin.

\section{Materials and Methods}

\section{Culture conditions}

HL-60 cells, human leukemia cell line was purchased from American Type Culture Collection. Cells were placed into $75 \mathrm{~cm}^{2}$ tissue culture flasks and grown at $37^{\circ} \mathrm{C}$ under a humidified, $5 \% \mathrm{CO}_{2}$ atmosphere in RPMI 1640 medium (Gibco BRL, Grand Island, NY, USA) supplemented with $10 \%$ fetal bovine serum and $2 \mathrm{mM}$ glutamine, 10,000 units/ml penicillin, $10 \mathrm{mg} / \mathrm{ml}$ streptomycin, and $2.5 \mu \mathrm{g} / \mathrm{ml}$ amphotericin B.

\section{Assay for cell viability}

General viability of cultured cells was determined by reduction of 3-(4,5-dimethylthiazol-2-yl)-2,5-diphenyltetrazolium bromide (MTT) to formazan (Oez et al., 1990). After $48 \mathrm{~h}$ incubation with daunorubicin, cells $\left(10^{4}\right.$ cells/ well) in 96 well plates were washed twice with phosphate-buffered saline (PBS). MTT (100 $\mu \mathrm{g} / 0.1 \mathrm{ml}$ PBS) was added to each well. Cells were incubated at $37^{\circ} \mathrm{C}$ for $1 \mathrm{~h}$, and dimethyl sulfoxide (DMSO) was added to dissolve the formazan crystals. The absorbance was measured at $570 \mathrm{~nm}$ with a model Spectra MAX PLUS (Molecular Devices, Sunnyvale, CA, USA).

\section{Caspase activity assay}

After treatment with daunorubicin (Sigma, St. Louis, MO, USA), cells were washed with ice-cold PBS and lysed in Triton X-100 buffer (0.5\% Triton X-100, $10 \mathrm{mM}$ EDTA, and $10 \mathrm{mM}$ Tris- $\mathrm{HCl}, \mathrm{pH} 7.5)$ for $30 \mathrm{~min}$ on ice. Cell lysates were mixed with caspase assay buffer (10\% glycerol, 2 mM DTT, and 20 mM HEPES, pH 7.5) containing caspase substrate, $20 \mathrm{mM}$ Ac-DEVD-AFC (Pharmingen, San Diego, CA, USA), and incubated for $1 \mathrm{~h}$ at $37^{\circ} \mathrm{C}$. AFC released by caspase was monitored using a spectrofluorometer with an excitation wavelength of 400 $\mathrm{nm}$ and an emission wavelength of $505 \mathrm{~nm}$.

\section{Western blot analysis of PARP and D4-GDI cleavage}

Cell extracts were separated by gel electrophoresis on a reducing SDS-polyacrylamide gel. Subsequently, the proteins were transferred onto a nitrocellulose membrane (Millipore, Bedford, MA, USA) using a semi-dry blotting apparatus (Bio-Rad, Munich, Germany). Prior to incubation with the PARP (Transduction Lab, Lexington, KY, USA) and D4-GDI antibodies (Pharmingen), the membrane was blocked with $2 \%$ BSA for 30 min. After washing, the proteins were detected with an alkalinephosphatase coupled secondary antibody.

\section{Detection of DNA fragmentation by gel electro- phoresis}

Cell pellets $\left(3 \times 10^{6}\right.$ cells) were resuspended in $500 \mu \mathrm{l}$ of lysis buffer (0.5\% Triton X-100, $10 \mathrm{mM}$ EDTA, and 10 $\mathrm{mM}$ Tris- $\mathrm{HCl}, \mathrm{pH} 8.0$ ) at room temperature for $15 \mathrm{~min}$ and centrifuged at $16,000 \mathrm{~g}$ for $10 \mathrm{~min}$. DNA was then extracted twice with phenol/chloroform (1:1), precipitated with ethanol, and resuspended in Tris/EDTA buffer (10 mM Tris- $\mathrm{HCl}, \mathrm{pH} 8.0$, and $1 \mathrm{mM}$ EDTA). DNA was analyzed after separation by gel electrophoresis ( $2 \%$ agarose).

\section{Protein determination}

Protein concentrations were determined by the method of Bradford (Bradford, 1976) with bovine serum albumin as the standard. All of the samples were assayed in triplicate.

\section{Statistical analysis}

Statistical analysis of the data was performed with an unpaired Student's $t$-test. Differences with $P<0.05$ were considered statistically significant.

\section{Results}

\section{Dose-dependent reduction of cell survival}

MTT conversion assay was used to determine the viability of HL-60 cells exposed to daunorubicin. As shown in Figure 1, about $40 \%$ of cells were viable after exposure to $250 \mathrm{nM}$ daunorubicin for $48 \mathrm{~h}$. The $\mathrm{IC}_{50}$ of daunorubicin for cell viability was $200 \mathrm{nM}$. 


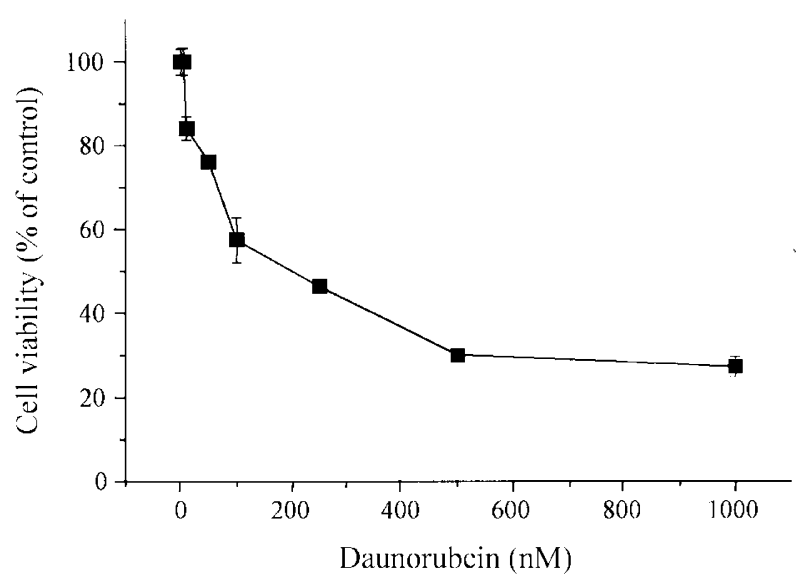

Figure 1. Effect of daunorubicin on cell viability. $\mathrm{HL}-60$ cells were treated with daunorubicin for $48 \mathrm{~h}$ and its viability was determined by MTT assay. The percentage of cell viability was calculated as a ratio of $A_{570}$ of control cells (treated with $0.05 \%$ PBS vehicle). Each value is the mean \pm S.E. of four independent experiments.

\section{Activation of caspase-3 during daunorubicin-induc- ed apoptosis}

DNA fragmentation and membrane changes were generally used as markers of apoptotic cell death. However, many researchers consider caspase activation as an even more reliable hallmark of apoptosis than DNA alterations (Nagata, 1997). Until now, several families of caspase have been reported and the caspase- 3 is well known in association with apoptosis (Nicholson and Thornberry, 1997). To address the involvement of caspase-3 in daunorubicin-induced apoptosis, Ac-DEVDAFC, fluorogenic caspase-3 substrate was used for caspase activity assay. As shown in Figure 2, daunorubicin caused dose- dependent activation of caspase3. However, daunorubicin did not induce the cleavage of Ac-YVAD-AFC, the caspase-1 substrate (data now shown). This protease activity was increased from $12 \mathrm{~h}$ and persisted until $24 \mathrm{~h}$ (Figure 2B), and reached its submaximal levels at $250 \mathrm{nM}$ after $24 \mathrm{~h}$ treatment (Figure 2A). This result was confirmed by Western blotting of PARP, a well- known caspase-3 substrate. Treatment with $250 \mathrm{nM}$ daunorubicin induced proteolytic cleavage of PARP, with the accumulation of the $85 \mathrm{kDa}$ cleaved products in a time dependent manner (Figure $2 \mathrm{C}$ ).

\section{Western blot analysis of D4-GDI cleavage}

To determine the participation of D4-GDI cleavage in daunorubicin-induced apoptosis, D4-GDI cleavage was investigated by Western blot analysis using a rabbit polyclonal antibody. Figure 4 showed that D4-GDI cleavage was induced after $12 \mathrm{~h}$ of incubation with daunorubicin (Figure 4A). In our model system, the time course of D4-GDI cleavage was similar to those of caspase activation and PARP cleavage. The $28 \mathrm{kDa}$

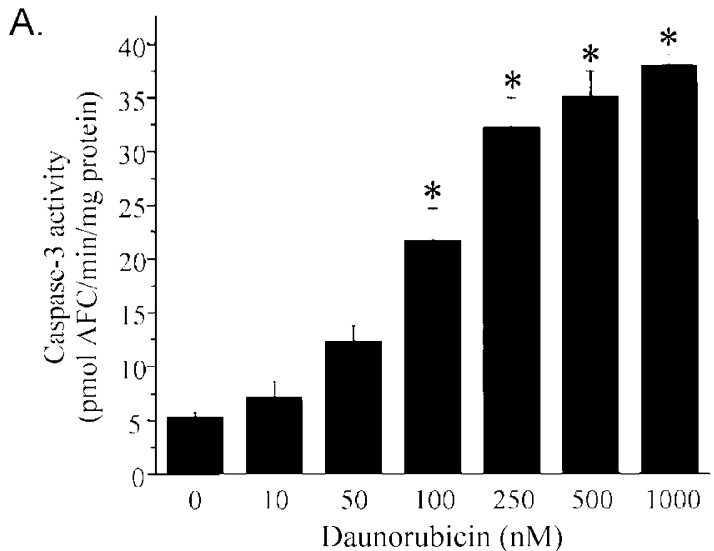

B.

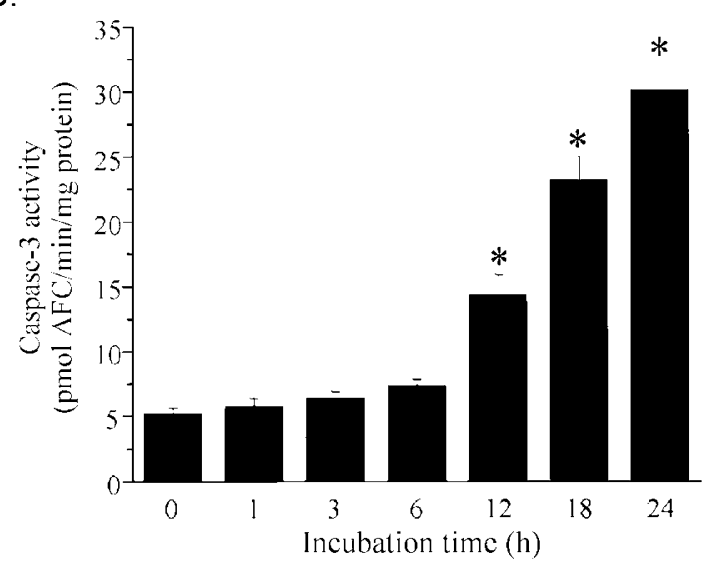

C.

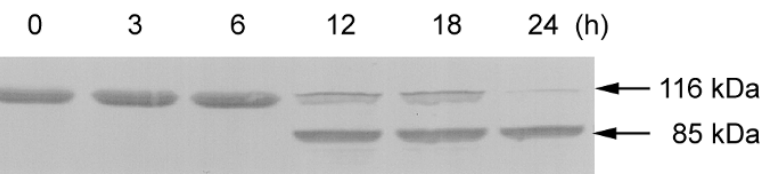

Figure 2. Dose- and time-dependent activations of caspase-3 after daunorubicin treatment. $\mathrm{HL}-60$ cells were treated with either a range of concentrations $(0-1000 \mathrm{nM})$ of daunorubicin for $24 \mathrm{~h}(\mathbf{A})$, or $250 \mathrm{nM}$ daunorubicin for the indicated time periods (B). Cytosolic extracts were prepared and assayed for caspase- 3 activity as described in Materials and Methods. Values represent mean \pm S.E. of six separate experiments. (Significant difference; ${ }^{*} P<0.05$, ${ }^{* *} P<0.01$ ). (C) HL-60 cells were treated with $250 \mathrm{nM}$ daunorubicin for indicated periods and the cleavage of PARP was analyzed by Western blotting as described in Materials and Methods.

D4-GDI band was specifically cleaved to a $23 \mathrm{kDa}$ fragment in a dose-dependent manner (Figure 4B).

Inhibition of apoptogenic signaling events by caspase-3 inhibitor

DNA extract from HL-60 cells incubated with $250 \mathrm{nM}$ daunorubicin for $48 \mathrm{~h}$ generated a characteristic ladder pattern of discontinuous DNA fragments on agarose gel electrophoresis (Figure 5, lane 2). When HL-60 cells were pretreated with $3 \mu \mathrm{M}$ Ac-DEVD-CHO, a selective caspase-3 inhibitor, both caspase-3 activation and PARP 


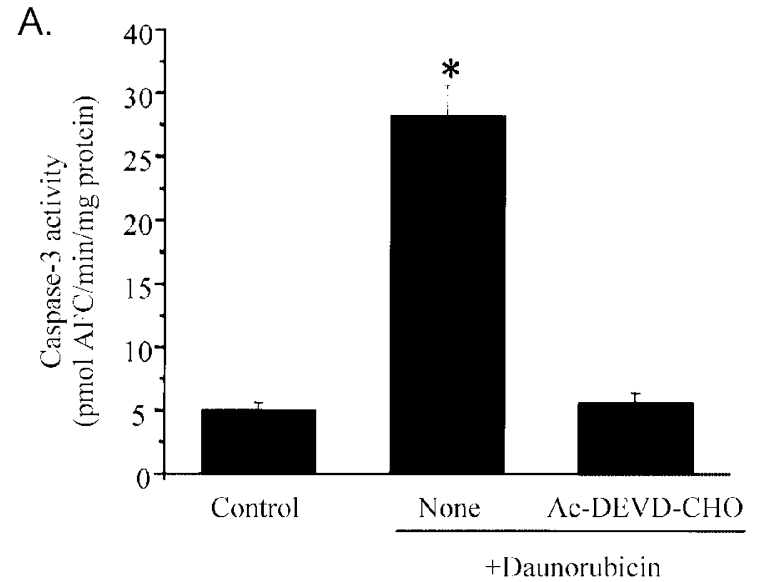

B.

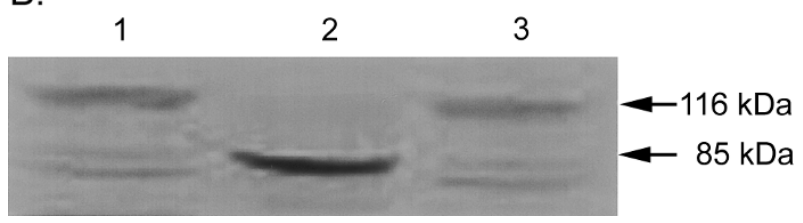

Figure 3. Inhibition of caspase activity by caspase-3 inhibitor. $\mathrm{HL}-60$ cells were preincubated with $3 \mu \mathrm{M} \mathrm{Ac}-\mathrm{DEVD}-\mathrm{CHO}$ for $3 \mathrm{~h}$ followed by treatment with $250 \mathrm{nM}$ daunorubicin for further $24 \mathrm{~h}$. Cytosolic extracts were prepared, and assayed for caspase-3 activity (A) or PARP cleavage was analyzed by Western blotting (B). Lane 1, control; Lane 2, $250 \mathrm{nM}$ daunorubicin; and Lane 3, $250 \mathrm{nM}$ daunorubicin with $3 \mu \mathrm{M}$ Ac-DEVD-CHO

A.
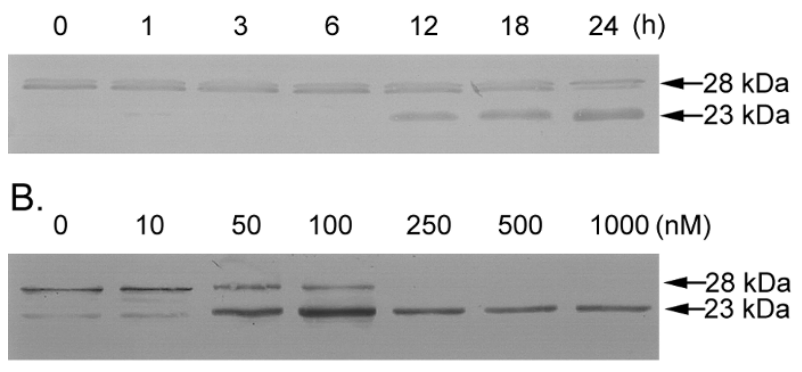

C.

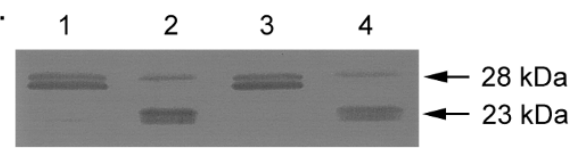

Figure 4. Identification of D4-GDI as a substrate of caspase-3. HL-60 cells were treated with $250 \mathrm{nM}$ daunorubicin for various times $(\mathbf{A})$, or a range of concentrations $(0-1000 \mathrm{nM})$ of daunorubicin for $24 \mathrm{~h}(\mathrm{~B})$, and the cleavage of D4-GDI was analyzed by Western blotting. To determine the responsible caspase for D4-GDI, HL-60 cells were pretreated with Ac-DEVD-CHO (3 $\mu \mathrm{M})$ or Ac-YVAD-CHO $(25 \mu \mathrm{M})$ for $3 \mathrm{~h}$ and followed by treatment with 250 $\mathrm{nM}$ daunorubicin for further $24 \mathrm{~h}$ (C). Lane 1, control; Lane 2, $250 \mathrm{nM}$ daunorubicin; Lane 3, $250 \mathrm{nM}$ daunorubicin with $3 \mu \mathrm{M}$ Ac-DEVD-CHO, and Lane 4, $250 \mathrm{nM}$ daunorubicin with $25 \mu \mathrm{M}$ Ac-YVAD-CHO. This experiment was repeated three times with similar results.

cleavage were completely abolished (Figure 3). Furthermore, the caspase- 3 inhibitor showed substantial inhibi-

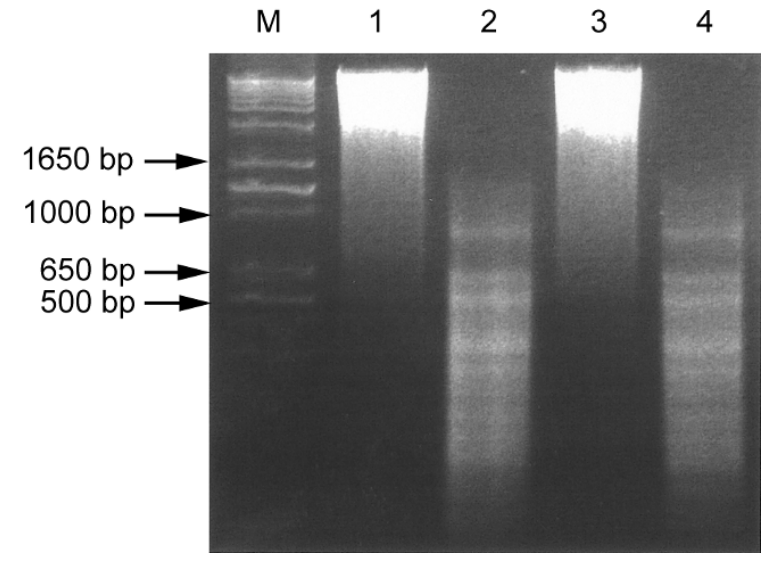

Figure 5. Inhibition of daunorubicin-induced DNA fragmentation by caspase3 inhibitor. HL-60 cells were treated with daunorubicin for $48 \mathrm{~h}$ in the presence of AC-DEVD-CHO or Ac-YVAD-CHO. DNA was extracted and analyzed by $2 \%$ agarose gel electrophoresis as described in Materials and Methods. Lane 1, control; Lane 2, $250 \mathrm{nM}$ daunorubicin; Lane 3, $250 \mathrm{nM}$ daunorubicin with $3 \mu \mathrm{M}$ Ac-DEVD-CHO, and Lane $4,250 \mathrm{nM}$ daunorubicin with $25 \mu \mathrm{M}$ Ac-YVAD-CHO.

tion of both D4-GDI cleavage (Figure 4, lane 3) and apoptosis at concentrations as low as $3 \mu \mathrm{M}$ (Figure 5, lane 3). The same treatment of HL-60 cells with caspase1 inhibitor up to $25 \mu \mathrm{M}$ did not inhibit daunorubicininduced D4-GDI cleavage (Figure 4C, lane 4) and apoptosis (Figure 5, lane 4). These results provide the evidence that caspase-3 is required for both D4-GDI cleavage and apoptosis, but caspase- 1 is not involved.

\section{Discussion}

D4-GDI, initially identified by its homology to Rho-GDI, functions as a negative regulator of Rho family GTPase. Its expression is mainly restricted to the cells of the hematopoietic system including bone marrow, thymus, spleen and lymph nodes (Lelias et al., 1993; Scherle et al., 1993). Actually, D4-GDI knockout mice were viable with normal thymocyte selection, lymphoid development, and immune responses (Yin et al., 1997). The mice did, however, show decreased apoptosis of lymph node cells after IL-2 withdrawal, which implicated the regulation of the Rho GTPase by D4-GDI in lymphocyte survival (or apoptosis) and responsiveness.

We implicated caspase- 3 as a possible mediator for D4-GDI cleavage in daunorubicin-treated HL-60 cells undergoing apoptosis. Caspases are cystein-containing, aspartate-specific proteases and key apoptosis mediators in many cells (Kim et al., 2000; Kwon et al. in press). Caspases can be divided into two major subgroups on the basis of their substrate specificity, sequence homology, and biochemical function: caspase-1 (ICE) like (caspase-1, -4, and 5) and caspase-3 like (caspase-2, -3 , and -10 ) proteases (Nicholson and Thornberry, 1997). 
While caspase- 1 seems to be mainly involved in inflammation (Cohen, 1997) and partially relating to apoptosis (Suzuki et al., 1998), the caspase-3 plays an important role in apoptosis.

D4-GDI is cleaved from a $28 \mathrm{kDa}$ to a $23 \mathrm{kDa}$ species and it contains two cleavage sites: a caspase- 3 cleavage site and caspase-1 cleavage site. $\mathrm{Na}$ et al. ( $\mathrm{Na}$ et al., 1996) reported that cleavage of D4-GDI and apoptosis could be inhibited by the addition of the caspase-1 inhibitor, Ac-YVAD-CMK in Fas-treated Jurkat T cells. In their in vitro experimental system, the authors also showed that incubation of D4-GDI with recombinant caspase-3 resulted in the cleavage of D4-GDI after aspartate and could be blocked by the addition of caspase-3 inhibitor. To confirm the cleavage site in daunorubicin-treated HL-60 cells, cells were pretreated with cell-permeable peptide inhibitors, and then D4-GDI cleavage and apoptosis were studied. We used AcDEVD-CHO or Ac-YVAD-CHO, which irreversibly inhibits caspase-3 and caspase-1 activities, respectively. In our experimental system, caspase-3 inhibitor, but not caspase1 inhibitor, protected daunorubicin-induced caspase activation, PARP cleavage, D4-GDI cleavage, and apoptosis. This is the first report that D4-GDI cleavage is induced by daunorubicin and specifically cleaved by activated caspase- 3 in HL-60 cells.

Many proteins are cleaved during apoptosis, but only a few of these substrates have shown to be related with apoptotic process. Activation of caspase- 3 cleaves PARP, a well-known substrate. This cleavage leads to its inactivation to prevent futile DNA repair cycles (Lazebnik et al., 1994). Although PARP is not essential for cell viability, the cleavage of PARP is another hallmark of apoptosis (Tewari et al., 1995). Treatment of HL-60 cells with $250 \mathrm{nM}$ daunorubicin induced proteolytic cleavage of $116 \mathrm{kDa}$ PARP, with accumulation of the $85 \mathrm{kDa}$ cleaved products. PARP cleavage was apparent at $12 \mathrm{~h}$ after daunorubicin treatment with similar time course of caspase activity and preceded DNA fragmentation.

Several proteins have been shown to translocate to the nucleus in different models of apoptosis. In the apoptotic pathway, caspases could degrade ICAD and cause its dissociation from CAD; CAD could then enter the nucleus to degrade the chromosomal DNA (Enari et al., 1998). D4-GDI resides in the cytoplasm of resting cells. Following cleavage by caspase, the $23 \mathrm{kDa}$ form of D4-GDI translocated to the nucleus (Krieser and Eastman, 1999). Further evaluation is needed to define the clear relationship between the nuclear translocation of cleaved D4-GDI and the demise of the cells.

\section{References}

Abo A, Pick E, Hall A, Totty N, Teahan CG, Segal AW. Activation of the NADPH oxidase involves the small GTP- binding protein p21rac1. Nature 1991;353:668-70

Bokoch GM, Der CJ. Emerging concepts in the Ras superfamily of GTP-binding proteins. Faseb J 1993;7:750-59

Bose R, Verheij M, Haimovitz-Friedman A, Scotto K, Fuks Z, Kolesnick R. Ceramide synthase mediates daunorubicininduced apoptosis: an alternative mechanism for generating death signals. Cell 1995;82:405-14

Bradford MM. A rapid and sensitive method for the quantitation of microgram quantities of protein utilizing the principle of protein-dye binding. Anal Biochem 1976;72:24854

Cohen GM. Caspases: the executioners of apoptosis. Biochem J 1997;326:1-16

Coso OA, Chiariello M, Yu JC, Teramoto H, Crespo P, Xu N, Miki T, Gutkind JS. The small GTP-binding proteins Rac1 and Cdc42 regulate the activity of the JNK/SAPK signaling pathway. Cell 1995;81:1137-46

Danley DE, Chuang TH, Bokoch GM. Defective Rho GTPase regulation by IL-1 beta-converting enzyme-mediated cleavage of D4 GDP dissociation inhibitor. J Immunol 1996;157:500-3

Enari M, Sakahira H, Yokoyama H, Okawa K, Iwamatsu A, Nagata S. A caspase-activated DNase that degrades DNA during apoptosis, and its inhibitor ICAD. Nature 1998;391:4350

Essmann F, Wieder T, Otto A, Muller EC, Dorken B, Daniel PT. GDP dissociation inhibitor D4-GDI (Rho-GDI 2), but not the homologous rho-GDI 1 , is cleaved by caspase- 3 during drug-induced apoptosis. Biochem J 2000;346 Pt 3:777-83

Gamen S, Anel A, Lasierra P, Alava MA, Martinez-Lorenzo MJ, Pineiro A, Naval J. Doxorubicin-induced apoptosis in human T-cell leukemia is mediated by caspase- 3 activation in a Fas-independent way. FEBS Lett 1997;417:360-64

Gewirtz DA. A critical evaluation of the mechanisms of action proposed for the antitumor effects of the anthracycline antibiotics adriamycin and daunorubicin. Biochem Pharmacol 1999;57:727-41

Geyer M, Wittinghofer A. GEFs, GAPs, GDls and effectors: taking a closer (3D) look at the regulation of Ras-related GTPbinding proteins. Curr Opin Struct Biol 1997;7:786-92

Guillemot JC, Kruskal BA, Adra CN, Zhu S, Ko JL, Burch P, Nocka K, Seetoo K, Simons E, Lim B. Targeted disruption of guanosine diphosphate-dissociation inhibitor for Rho-related proteins, GDID4: normal hematopoietic differentiation but subtle defect in superoxide production by macrophages derived from in vitro embryonal stem cell differentiation. Blood 1996;88: 2722-31

Jaffrezou JP, Levade T, Bettaieb A, Andrieu N, Bezombes C, Maestre N, Vermeersch S, Rousse A, Laurent G. Daunorubicin-induced apoptosis: triggering of ceramide generation through sphingomyelin hydrolysis. Embo J 1996;15:2417-24

Kettritz R, Xu YX, Faass B, Klein JB, Muller EC, Otto A, Busjahn A, Luft FC, Haller H. TNF-alpha-mediated neutrophil apoptosis involves Ly-GDI, a Rho GTPase regulator. J Leukoc Biol 2000;68:277-83 
Kim HS, Jeong SY, Lee JH, Kim BE, Kim JW, Jeong SW, Kim IK. Induction of apoptosis in human leukemia cells by 3deazaadenosine is mediated by caspase-3-like activity. Exp Mol Med 2000;32:197-203

Kothakota S, Azuma T, Reinhard C, Klippel A, Tang J, Chu K, McGarry TJ, Kirschner MW, Koths K, Kwiatkowski DJ, Williams LT. Caspase-3-generated fragment of gelsolin: effector of morphological change in apoptosis. Science 1997;278:294-98

Krieser RJ, Eastman A. Cleavage and nuclear translocation of the caspase 3 substrate Rho GDP-dissociation inhibitor, D4GDI, during apoptosis. Cell Death Differ 1999;6:412-19

Kwon KB, Yang JY, Ryu DG, Rho HW, Kim JS, Park JW, Kim $\mathrm{HR}$, Park BH. Vibrio vulnificus cytolysin induces superoxide anion-initiated apoptotic signaling pathway in human ECV304 cells. J Biol Chem 2001;276:47518-23.

Lazebnik YA, Kaufmann SH, Desnoyers S, Poirier GG, Earnshaw WC. Cleavage of poly(ADP-ribose) polymerase by a proteinase with properties like ICE. Nature 1994;371:346-47

Lelias JM, Adra CN, Wulf GM, Guillemot JC, Khagad M, Caput D, Lim B. cDNA cloning of a human mRNA preferentially expressed in hematopoietic cells and with homology to a GDP-dissociation inhibitor for the rho GTP-binding proteins. Proc Natl Acad Sci U S A 1993;90:1479-83

Liu X, Zou H, Slaughter C, Wang X. DFF, a heterodimeric protein that functions downstream of caspase-3 to trigger DNA fragmentation during apoptosis. Cell 1997;89:175-84

Minden A, Lin A, Claret FX, Abo A, Karin M. Selective activation of the JNK signaling cascade and c-Jun transcriptional activity by the small GTPases Rac and Cdc42Hs. Cell 1995; 81:1147-57

Na S, Chuang TH, Cunningham A, Turi TG, Hanke JH, Bokoch GM, Danley DE. D4-GDI, a substrate of CPP32, is proteolyzed during Fas-induced apoptosis. J Biol Chem 1996; 271:11209-13

Nagata S. Apoptosis by death factor. Cell 1997;88:355-65

Narumiya S. The small GTPase Rho: cellular functions and signal transduction. J Biochem (Tokyo) 1996;120:215-28

Nicholson DW, Thornberry NA. Caspases: killer proteases. Trends Biochem Sci 1997;22:299-306

Oberhammer FA, Hochegger K, Froschl G, Tiefenbacher R, Pavelka M. Chromatin condensation during apoptosis is accompanied by degradation of lamin $A+B$, without enhanced activation of cdc2 kinase. J Cell Biol 1994;126:827-37

Oez S, Platzer E, Welte K. A quantitative colorimetric method to evaluate the functional state of human polymorphonuclear leukocytes. Blut 1990;60:97-102

Olofsson B. Rho guanine dissociation inhibitors: pivotal molecules in cellular signalling. Cell Signal 1999;11:545-54

Polverino AJ, Patterson SD. Selective activation of caspases during apoptotic induction in HL-60 cells. Effects Of a tetrapeptide inhibitor. J Biol Chem 1997;272:7013-21

Rao L, Perez D, White E. Lamin proteolysis facilitates nuclear events during apoptosis. J Cell Biol 1996;135:1441-55

Rickers A, Brockstedt E, Mapara MY, Otto A, Dorken B, Bommert K. Inhibition of CPP32 blocks surface IgM-mediated apoptosis and D4-GDI cleavage in human BL60 Burkitt lymphoma cells. Eur J Immunol 1998;28:296-304

Ridley AJ, Hall A. The small GTP-binding protein rho regulates the assembly of focal adhesions and actin stress fibers in response to growth factors. Cell 1992;70:389-99

Sasaki T, Takai Y. The Rho small G protein family-Rho GDI system as a temporal and spatial determinant for cytoskeletal control. Biochem Biophys Res Commun 1998;245:641-45

Scherle P, Behrens T, Staudt LM. Ly-GDI, a GDP-dissociation inhibitor of the RhoA GTP-binding protein, is expressed preferentially in lymphocytes. Proc Natl Acad Sci U S A 1993; 90:7568-72

Suzuki A, Kawabata T, Kato M. Necessity of interleukin-1beta converting enzyme cascade in taxotere-initiated death signaling. Eur J Pharmacol 1998;343:87-92

Tewari M, Quan LT, O'Rourke K, Desnoyers S, Zeng Z, Beidler DR, Poirier GG, Salvesen GS, Dixit VM. Yama/CPP32 beta, a mammalian homolog of CED-3, is a CrmA-inhibitable protease that cleaves the death substrate poly(ADP-ribose) polymerase. Cell 1995;81:801-9

Turnbull KJ, Brown BL, Dobson PR. Caspase-3-like activity is necessary but not sufficient for daunorubicin-induced apoptosis in Jurkat human lymphoblastic leukemia cells. Leukemia 1999;13:1056-61

Xiang J, Chao DT, Korsmeyer SJ. BAX-induced cell death may not require interleukin 1 beta-converting enzyme-like proteases. Proc Natl Acad Sci U S A 1996;93:14559-63

Yin L, Schwartzberg P, Scharton-Kersten TM, Staudt L, Lenardo M. Immune responses in mice deficient in Ly-GDI, a lymphoid-specific regulator of Rho GTPases. Mol Immunol 1997;34:481-91

Zhang S, Han J, Sells MA, Chernoff J, Knaus UG, Ulevitch RJ, Bokoch GM. Rho family GTPases regulate p38 mitogenactivated protein kinase through the downstream mediator Pak1. J Biol Chem 1995;270:23934-36 